\title{
EGFR NM_005228.3:c.2239_2247del9
}

National Cancer Institute

\section{Source}

National Cancer Institute. EGFR NM 005228.3:C.2239 2247del9. NCI Thesaurus. Code C98555.

A deletion of nine nucleotides from the coding sequence of the EGFR gene from position 2239 through 2247. 